\title{
Amperometric Biosensors for Glucose and Lactate with Applications in Food Analysis: A Brief Review
}

\author{
Totka Dodevska ${ }^{\star}$, Yanna Lazarova and Ivan Shterev
}

\author{
Department of Organic Chemistry and Inorganic Chemistry, University of Food Technologies, 26, \\ Maritsa Boulevard, Plovdiv 4002, Bulgaria \\ *Corresponding author: E-mail: dodevska@mail.bg \\ Tel.: +35932603 679; Fax: +35932644102
}

Received: 05-15-2019

\begin{abstract}
Over the past two decades, electrochemical biosensor devices have received great attention in the field of food analysis owing to their attractive performances. In the food industry the quality control during manufacturing process and final products requires quick and reliable analytical methods. A promising alternative to the traditional analytical techniques are the electrochemical enzymatic biosensors - devices that combine the robustness of electrochemical techniques with the specificity of biological recognition processes and offer great advantages due to size, cost, sensitivity, selectivity, and fast response. This brief review has attempted to summarise the literature on the recent progress in the development of enzyme biosensors with amperometric detection for quantitative analysis of glucose and lactate in various food samples. The review concludes with an outlook on the future challenges and perspectives in this area.
\end{abstract}

Keywords: Biosensors, Glucose, Lactate, Food analysis

\section{Introduction}

In food quality control, the development of reliable, sensitive and selective methods for fast, precise sensing and quantification of food ingredients and supplements, ${ }^{1-4}$ toxicants, ${ }^{5-9}$ antibiotics, and allergens, ${ }^{10}$ is an issue of constantly increasing importance. ${ }^{11-16}$ Recently, as a new direction of the analytical technology is distinguished the development of electrochemical enzymatic biosensors complex systems that include an immobilised enzyme (bioelement) and a physical transducer of the signal which may be potentiometric or amperometric, as well as a device for signal reading and processing. The amperometric biosensors have a superior sensitivity and better linear range than potentiometric devices and are the most successful commercially. In particular, in food analysis the majority of the electrochemical biosensors are based on the amperometric electrodes in combination with oxidases enzymes and it seems that these systems will continue to dominate the technology of commercial biosensors.

The electrochemical biosensing systems provide the opportunity for an accurate, highly selective, sensitive and susceptible to automatisation analysis, and are a promising alternative of the traditional analytical techniques, that are time-consuming and often require specific expensive equipment or multi-step painstaking procedures for sample preparation. Not at least, the electrochemical biosensors offer the possibility of miniaturisation and potential for development of portable hand-held devices for real time monitoring. Fully automated biosensor systems are being developed and adapted for continuous on-line or periodic monitoring of various processes in food industry.

The amperometric enzyme-based biosensors are dominant in the food sector since they have a number of advantages in determining submilimolar levels of the analyte: extremely low detection limit, high sensitivity, wide linear range, fast response and relatively low cost of analysis. Generally, biosensors do not require extensive sample preparation and in most cases only a suitable dilution is needed; the high specificity and the wide linear dynamic range allow direct quantification of the target analyte. The results are obtained within minutes, which is particularly important as it allows corrective actions during manufacturing process.

Amperometry is based on the measurement of the current resulting from the electrochemical oxidation or reduction of an electroactive species. The resulting steadystate current is proportional to the bulk concentration of the analyte. Three-electrode set-up has to be used for am- 
perometric measurements - a working electrode (electrically conductive material combined with an immobilised enzyme), that is maintained under constant potential, reference and auxiliary electrode. The working electrode is either metal (usually $\mathrm{Pt}, \mathrm{Au}$ ) or carbon-based material (glassy carbon, graphite, screen-printed or carbon paste electrode). As the immobilisation of enzymes on the electrode surface is a necessary and critical step in the design of biosensors, the transducer should provide a stable surface for immobilisation of biomolecules while retaining their structure, mobility and biocatalytic activity.

In order to enhance the sensitivity of biosensors, nanomaterials like metal and metal oxide nanoparticles, ${ }^{17-20}$ carbon nanotubes $(\mathrm{CNTs}),{ }^{20-22}$ graphene and its derivates, ${ }^{22-27}$ are used in the construction of transducers for increasing the electrode surface area. As a result the nanostructured electrodes possess unique characteristics such as large surface-to-volume value and extremely high catalytic efficiency. Nanomaterials not only accelerate the electron transfer and so improve the response characteristics of the transducers, but also act as immobilisation matrices. The immobilisation of enzymes on nanomaterials enhanced the amount of the enzyme loading, supported the retention of biocatalytic activity and therefore improved the sensitivity of the biosensor device. Electrochemical biosensors incorporating enzymes with nanomaterials, which combine the recognition and catalytic properties of enzymes with the electronic properties of various nanomaterials, are new materials with synergistic properties and they have excellent prospects for interfacing biological recognition events by electronic signal transduction with extremely high sensitivity and stability. ${ }^{28}$

Within the family of nanomaterials, CNTs are arousing growing interest, mainly due to their exceptional structural, electronic and chemical properties. CNTs have a unique tubular structure, good biocompatibility and modifiable sidewall, making them ideal candidates for the construction of biosensors with high performances. CNTbased biosensors generally have higher sensitivities, lower limits of detection, and faster electron transfer kinetics than traditional carbon electrodes, but to fully explore the potential of the complex enzyme/CNTs, it is essential to find optimal methods for enzyme immobilisation. ${ }^{29} \mathrm{CNTs}$ can be functionalised with hydroxyl, carboxyl, carbonyl or amino groups. Functionalised CNTs exhibit increased solubility, catalytic activity and biocompatibility, since enhance the immobilisation of biorecognition molecules on the electrode surface facilitating covalent bonding. Combination of CNTs with other nano-sized materials such as metal nanoparticles for surface modification of electrodes has proved to be feasible and more effective than using either nanomaterial alone in biosensing design. Several quality review papers, published in the past decade, comprehensively discussed the uses of novel functional nanomaterials as key components of various electrochemical biosensors, some of which were successfully applied in food analysis, and provided trends in biosensing strategies based on nanomaterials. ${ }^{30-37}$

For biosensing purposes, the immobilisation procedure must be reproducible and stable to ensure extended working and long-time storage stability. Factors such as accuracy of measurements, sensor-to-sensor reproducibility and operational lifetime are drastically influenced by enzyme stability, i.e. the enzyme immobilisation appears as a key factor to develop efficient biosensors with appropriate analytical performances. ${ }^{38}$ Moreover, the immobilisation matrix may function only as a support or may also be concerned with mediation of the signal transduction mechanism. ${ }^{31}$ A variety of enzyme immobilisation methods are applied including physical adsorption (van der Waals interactions or hydrogen bonding), covalent attachment, physical entrapment in polymer matrices, cross-link formation (the process uses bifunctional agent forming a "bridge" between protein and electrode surface; most often used cross-linker is glutaraldehyde), and self-assembly formed monolayer (long-chain alkylthiols, amines, or disulphides are used). As a promising strategy, sol-gels also have been used to immobilise enzymes - the technique provides an environment similar to that of the enzyme in solution. ${ }^{39}$ The choice of an appropriate immobilisation method is strongly individual and depends on the nature of the enzyme used, transducer type, physicochemical properties of the analyte, and biosensor's operating conditions. ${ }^{40}$

Amperometric biosensors can be classified into three categories in accordance with the principle of the response generation: ${ }^{41}$

1/ first generation biosensors - the signal corresponds to electrochemical reaction of an active reagent or product, involved in the biochemical transformation of the target compound; they are also called "mediator-less" amperometric biosensors;

$2 /$ second generation biosensors - the response results from the oxidation/reduction of the redox mediator (freely diffusing low molecular weight compound that effectively shuttles electrons between the electrode surface and the enzyme's active centre);

3/ third generation biosensors - the enzyme's active centre has a direct electrical connection to the transducer and the concentration of the analyte is directly proportional to the redox current generated at the polarised electrode.

As a general rule, designing electrochemical biosensors requires consideration of both the target analyte and the complexity of the sample in which the analyte has to be quantified. Enzymatic electrochemical biosensors are based on biological recognition - enzyme macromolecules have binding "pockets" with unique hydrogen bonding and electrostatic biorecognition patterns to achieve extremely high specificity to the substrate. In order to operate, the enzyme must be stable and available to catalyse a 
specific biochemical reaction under the operating conditions of the biosensor. However, in electrochemical biosensing the detecting device is directly in contact with the analysed sample and interferents are a serious problem. Food/beverage samples contain a number of low- and high-molecular weight interfering compounds: oxidisable acids (ascorbic acid, citric acid, caffeic acid, vanillic acid, etc.) and bases (amines, etc.), sugars, proteins, lipids, polyphenols, pigments, pesticides, etc. Some of these compounds are electroactive and capable to produce current signal, while others may cause electrode passivation/biofouling by adsorption. In particular, at a suitable applied potential phenolic compounds polymerise to form a polymeric film on the electrode surface, thereby decreasing biosensor signal.

In order to minimise the contribution of interfering species, several approaches have been proposed in development of glucose and lactate biosensors. The use of artificial electron transferring agent (mediator) in the construction of biosensors leads to lowering the operating potential and so reduces the interference effects of other electrochemically active species. The most commonly used mediators are ferrocene derivates, Meldola blue, Prussian blue, toluidine blue, methylene green, and osmium complex redox polymers.

The other approach is to use permselective membrane to restrict the access of the interfering substances. Different types of polymeric membranes serving as a barrier, ensuring the selective penetration of the substrate being determined into the layer with immobilised enzyme, have been introduced in biosensor design. Permselective membranes such as cellulose acetate, polyaniline, and polypyrrole are based on size exclusion, whereas membranes such as Nafion and polyvinylpyridine are based on charge exclusion. The polymeric films used for this purpose are usually solvent-cast or electropolymerised. In contrast to solvent-cast films, where it is difficult to obtain uniform thickness coating, electropolymerisation offers advantages with respect to thickness control, reproducibility, and uniformity of the polymer film on the electrode surface.

Cellulose acetate and polypyrrole (PPy) membranes have been reported to have a good interference effect and they are one of the first polymers used to improve biosensor's selectivity. The polymer structure is distinguished by small-sized pores and allows only small molecules to pass through. Overoxidised PPy rejects proteins and acts as an ion-exchange membrane - forms an ultra-thin film that is ion-selective against anions. Recently, successfully applied in construction of selective electrochemical biosensors is Nafion - sulphonated tetrafluoroethylene copolymer. Nafion membranes possess excellent mechanical stability, low swelling capability in aqueous media, and high cation-conductive properties. The negative charge of Nafion prevents the diffusion of anionic components through polymer film, coated on the electrode surface, and acts as a highly effective barrier for various interferences, significantly enhancing biosensor selectivity. Polystyrene and polyurethanes with phospholipid polar groups have also been used as membrane coatings.

Using amperometric biosensors, various analytes such as alcohols, sugars, pesticides, etc. can be determined quantitatively in food samples with extremely high selectivity and sensitivity. Biosensor arrays save time as they offer the possibility for detecting multiple target analytes simultaneously. Single enzyme-based and multi-enzyme-based biosensor systems are developed and successfully applied in food processing for monitoring food quality and safety. ${ }^{30,31,42-44}$ In this review, we have summarised and discussed the recent development of enzyme-based amperometric biosensors for glucose and lactate and their applications in food industry. Finally, future trends in amperometric biosensor development are briefly discussed. Despite the clear advantages of electrochemical biosensor systems, compared to classical analytical techniques, there is a long way to emerge from the research laboratory to the marketplace. Considerable efforts should be focused on the development of commercially available highly sensitive, miniaturised, and portable devices for fast and reliable analysis. In this context, the synergy between nanotechnology, biotechnology, and electronics, will have a pronounced influence on the development of new electrochemical biosensing devices in the foreseeable future.

\section{Amperometric Glucose Biosensors}

Information about glucose content of foods and beverages is essential for both producers and consumers. Glucose monitoring is crucial in tracing the fermentation processes in the wine, brewing and dairy industries. In food control, the accurate evaluation of the glucose content in foods is extremely important for the maintenance of its physiological level in blood of diabetic individuals. According to the World Health Organisation (WHO) ${ }^{45}$ the number of people with diabetes has risen from 108 million in 1980 to 422 million in 2014; WHO predicts that the diabetes will be the seventh leading cause of death in 2030.

In the field of product authentication, the determination of glucose content in honey or wine can prove their originality and even help to identify the region of the world from which the product originates. ${ }^{46,47}$

The enzyme glucose oxidase (GOx) (EC 1.1.3.4), frequently used for glucose detection, is unusually sustainable towards environmental influences, and is relatively inexpensive. GOx is a homodimeric enzyme (flavoprotein) with an FAD molecule non-covalently bound at the active site of each $80 \mathrm{kDa}$ subunit. GOx catalyses oxidation of $\beta$-D-glucose, utilizing molecular oxygen as an electron acceptor, to produce $\mathrm{D}$-gluconic acid and hydrogen peroxide $\left(\mathrm{H}_{2} \mathrm{O}_{2}\right)$ : 


$$
\begin{aligned}
& \beta-\mathrm{D}-\text { Glucose }+\mathrm{O}_{2} \stackrel{\text { GOx }}{\longrightarrow} \\
& \mathrm{D}-\text { gluconic acid }+\mathrm{H}_{2} \mathrm{O}_{2}
\end{aligned}
$$

This reaction allows quantitative determination of glucose by detecting the amount of oxygen, consumed during the reaction, or detecting the amount of $\mathrm{H}_{2} \mathrm{O}_{2}$, product of the reaction. The first method has significant drawbacks: the concentration of oxygen in aqueous solutions is high, making it difficult to determine low concentrations of the analyte; moreover, in the real samples the oxygen concentration is not constant and may vary. Quantitatively glucose can be determined by measuring the current generated from the oxidation or reduction of $\mathrm{H}_{2} \mathrm{O}_{2}$. Hydrogen peroxide can be oxidised at a conventional Pt-electrode, but the direct electrooxidation of $\mathrm{H}_{2} \mathrm{O}_{2}$ requires high overpotential and quantification suffers from interference of other compounds. The process is accompanied by co-oxidation of interfering species that are present in the real samples. For instance, food samples usually contain a high concentration of ascorbic acid and/or citric acid. Both species are classical interferents in the electrochemical analysis. As a result, the registered signal is higher and does not correspond to the real concentration of the analyte. The problem can be solved partially by using permselective barrier (membrane) to block the access of this type of interfering species at the electrode surface.

Conventional amperometric glucose biosensor that includes a cellulose acetate membrane, treated with amylamine and glutaraldehyde, is described. ${ }^{48}$ The system operates at a potential of $0.65 \mathrm{~V}$ (vs. $\mathrm{Ag} / \mathrm{AgCl}, 3 \mathrm{M} \mathrm{KCl}$ ) with linearity of the signal up to $320 \mathrm{mM}$ glucose. This type of biosensor has been tested successfully for glucose determination in orange juice and tonic samples, and the results are similar to those obtained with the conventional measurement method (spectrophotometry).

In order to improve the electrochemical response of $\mathrm{H}_{2} \mathrm{O}_{2}$ (resp., the selectivity of glucose detection), the applied potential should be efficiently lowered. The low-potential detection of $\mathrm{H}_{2} \mathrm{O}_{2}$ is one of the most successful strategies for oxidase-based biosensors providing both sensitivity and extremely high selectivity in the presence of easily oxidisable compounds. A number of researches confirm that the optimal potentials for biosensor applications are close to $0.0 \mathrm{~V}$ (vs. $\mathrm{Ag} / \mathrm{AgCl}$ ) where, depending on the type of the electrode material, the current of $\mathrm{H}_{2} \mathrm{O}_{2}$ reduction may be several hundred times higher than the current of oxygen reduction. At such low potentials the interference of electroactive substances in the real samples is reduced or totally eliminated.

Recently, there are a numerous studies on the development of effective electrocatalysts for reduction of $\mathrm{H}_{2} \mathrm{O}_{2}$ by modifying the surface of the bare electrode with suitable electrocatalytic active phase that facilitates electron-transfer process - metal or metal oxide particles, bimetallic nanomaterials, conducting polymer films, metal complexes, etc. In this connection, new carbonaceous electrodes modified with microquantities of noble metals $(\mathrm{Pd}, \mathrm{Pd}+\mathrm{Pt}, \mathrm{Pd}+\mathrm{Au})$ have been proven to be promising transducers for the development of biosensors. On their basis, improved model biosensor systems for glucose ${ }^{49-51}$ and xanthine $e^{50,52,53}$ analysis have been developed.

In some cases, electrodes modified with horseradish peroxidase (HRP) as an efficient biocatalyst for reduction of $\mathrm{H}_{2} \mathrm{O}_{2}$ are used. The development of bienzymatic systems that include both GOx and HRP, leads to a significant increase in the selectivity of the analysis, but also considerably complicates the architecture of the biosensor.

A number of research groups have used Prussian Blue (ferric hexacyanoferrate) as an "artificial peroxidase". At an optimal potential for sensor/biosensor applications $0.0 \mathrm{~V}$ (vs. Ag/AgCl) Prussian Blue (PB) has been shown to be highly active and selective catalyst in $\mathrm{H}_{2} \mathrm{O}_{2}$ electroreduction in the presence of oxygen (the current of $\mathrm{H}_{2} \mathrm{O}_{2}$ reduction was several hundred times higher than of oxygen reduction) ${ }^{54}$ Here it should be noted that the stability associated with limited working $\mathrm{pH}$-range of the $\mathrm{PB}$-based transducers is a crucial point commonly raised by referees as an objection against their practical applications.

Carbon film resistor electrodes have been evaluated as transducers for the development of oxidase-based enzyme biosensors. ${ }^{55}$ The electrodes were first modified with $\mathrm{PB}$ and then covered by a layer of covalently immobilised oxidase enzymes. These enzyme electrodes were used to detect the substrate of the oxidase (glucose, ethanol, lactate, glutamate) via reduction of hydrogen peroxide at 0.05 $\mathrm{V}$ vs. $\mathrm{Ag} / \mathrm{AgCl}$ in the low micromolar range at response time within $2 \mathrm{~min}$. Finally, the glucose, ethanol, and lactate electrochemical biosensors were used to analyse complex food matrices - must, various wines, and yoghurt. Data obtained by the single standard addition method were compared with a spectrophotometric reference method and showed good correlation, indicating that the electrodes are suitable for food analysis. However, the lifetime of the enzyme electrodes, stored 1 month in $0.1 \mathrm{M}$ phosphate buffer $\mathrm{pH} 7.0$ at temperature of $4{ }^{\circ} \mathrm{C}$, evaluated by running two calibration curves per week, was unsatisfactory - glucose biosensor retained $50-60 \%$ of its initial activity, while the activity of lactate biosensor was in the $20-40 \%$ range.

For industrial control, the use of automated methods is desirable and the flow injection analysis (FIA) is worthwhile. In this connection, the combination of the FIA system with amperometric biosensors became attractive due to its versatility, simplicity, and suitability for large-scale analyses. Biosensor developed on the basis of glassy carbon with electrodeposited Prussian Blue, immobilised GOx, and coating of a Nafion polymer layer, was used for industrial routine measurements of glucose in instant coffee samples. ${ }^{56}$ The linear concentration range is from 0.15 to $2.5 \mathrm{mM}$ glucose $(\mathrm{RSD}<1.5 \%)$ with detection limit of $0.03 \mathrm{mM}$. The system has a high operational stability and 
fast response which enables the measurement of 60 samples per hour and is suitable for automated monitoring of glucose in commercial soluble coffee.

An amperometric biosensor system with ferrocene as a mediator and a Nafion protective film operating at $0.25 \mathrm{~V}$ (vs. $\mathrm{Ag} / \mathrm{AgCl}, 3 \mathrm{M} \mathrm{KCl}$ ) was used to determine the glucose content in wine. ${ }^{57}$ Neutral $\operatorname{Red}^{58}$ and osmium polymers $^{59}$ were also successfully used as mediators for glucose analysis in wines and alcoholic beverages.

The support material, used for enzyme immobilisation, should possess mechanical stability and rigidity, as well as high affinity to proteins. Recently, in biosensor design chitosan has been widely used as a support for enzyme immobilisation. ${ }^{60,61}$ Chitosan is a natural linear amine-rich polysaccharide, non-toxic biocompatible polymer, distinguished by its ability to form flexible, transparent membranes with sufficient mechanical strength, high adhesive consistency and protein-binding capacity. The common drawback of the direct entrapment of enzyme in the polymer is relatively low efficacy of enzyme loading. This results in inconsistency in amperometric response and reduced sensitivity during long-term operation of the biosensor. Therefore, for better enzyme loading cross-linking agents (glutaraldehyde GA, thiol linkers) have been combined with polymer layers. An amperometric enzyme electrode based on GOx immobilised on chitosan membrane via cross-linking showing the highest response to glucose utilised $0.21 \mathrm{ml} \mathrm{cm}^{-2}$ thick chitosan membrane. ${ }^{60}$ Under optimal experimental conditions ( $\mathrm{pH}$ 6.0, temperature of $35^{\circ} \mathrm{C}$, and applied potential of $0.6 \mathrm{~V}$ vs. $\mathrm{Ag} / \mathrm{AgCl}$ ) detection limit of $0.05 \mathrm{mM}$ was reached. The performance of the biosensor was evaluated by determining the glucose content in fruit homogenates; the accuracy was compared to that of a commercial glucose assay kit and results indicated that the present immobilisation method and measurement procedure are reliable and have potential for commercial application.

An amperometric biosensor, distinguished by its simplicity and relative low cost, based on GOx, hydrogel, of chitosan and highly ordered titanium dioxide nanotube arrays $\left(\mathrm{TiO}_{2} \mathrm{NTAs}\right)$ has been evaluated by Artigues et al. ${ }^{62}$ In the recent years, $\mathrm{TiO}_{2}$ NTAs has been extensively studied and proved as material suitable as an electrochemical interface for biosensor applications. $\mathrm{TiO}_{2} \mathrm{NTAs}$ offer excellent biocompatibility, high active area that allows immobilisation of a high number of enzyme molecules, and remarkable ability to promote charge transfer processes. The GOx-Chitosan/ $/ \mathrm{TiO}_{2}$ NTAs biosensor showed a sensitivity of $5.46 \mu \mathrm{A} \mathrm{mM}^{-1}$ with a linear range from 0.3 to $1.5 \mathrm{mM}$; no significant interferences from fructose, ascorbic acid, and citric acid were obtained. Measurements done with the studied biosensor showed high repeatability (RSD equal to $0.8 \%$ ) and reproducibility (RSD equal to $2.5 \%$ ). The biosensor has good storage stability - after 30 days $85 \%$ of its initial current response was retained. Glucose content of different food samples - soft drinks, milk, yo- ghurt, fried tomato, and ketchup, was measured using the biosensor and compared with the respective HPLC value. In all the cases, the glucose concentration was determined with sufficient accuracy (deviation less than 10\%) regardless of the matrix composition.

Conducting (poly)thiophene films were also applied as support material in designing glucose biosensors. The development of biosensors by electrochemical polymerisation of (poly)thiophenes, namely $2,2^{\prime}$-bithiophene $\left(2,2^{\prime}\right.$ BT) and 4,4'-bis(2-methyl-3-butyn-2-ol)-2,2'-bithiophene $\left(4,4^{\prime}-\mathrm{bBT}\right)$, followed by immobilisation of GOx on the films, is described. ${ }^{63} \mathrm{~N}$-cyclohexyl- $N^{\prime}$-(2-morpholinoethyl) carbodiimide metho- $p$-toluenesulphonate (CMC) was used as a condensing agent, and $p$-benzoquinone (BQ) was used as a redox mediator. The enzyme electrodes based on films of 2,2'-BT and 4,4'-bBT were tested for their ability to detect glucose in synthetic and real samples - pear, apricot, and peach fruit juices.

A simple inexpensive paper-based amperometric glucose biosensor based on Prussian Blue-modified screen-printed carbon electrode (SPCE) was developed. ${ }^{64}$ The use of cellulose paper proved to be a simple, "ideal", and green biocompatible immobilisation matrix for GOx. The glucose biosensor allowed a small amount $(0.5 \mu \mathrm{L})$ of sample solution for glucose analysis and had a linear calibration range from 0.25 to $2.00 \mathrm{mM}$ with a detection limit of $0.01 \mathrm{mM}$ glucose. Its analytical performance was demonstrated in analysis of selected commercial glucose beverages. Despite the simplicity of the immobilisation method, the biosensor retained $72 \%$ of its activity after a storage period of 45 days.

Glucose biosensor based on GOx, poly(3,4-ethylenedioxythiophene) (PEDOT) and anthranilic acid (AA) doped with poly(4-styrenesulphonic acid) (PSSH) was successfully applied for determination of glucose concentration in food samples such as grape juice and honey. ${ }^{65}$ After a careful examination of the experimental data, it can be stated that the presented biosensor will be an appropriate tool for measurement of glucose concentration in food samples, provided that the concentration of ascorbic acid in such samples remains below the level of $0.1 \mathrm{mM}$.

Glucose oxidase was immobilised in conducting copolymers of three different types of poly(methyl-methacrylate-co-thienyl-methacrylate). ${ }^{66}$ Immobilisation of enzyme was carried out by entrapment in conducting polymers during electrochemical polymerisation of pyrrole on the copolymer electrodes. The amount of glucose in orange juices was investigated by using the developed enzyme electrodes.

In biosensors development, incorporation of biocatalyst within the bulk of carbon matrix offers some advantages such as: high stability, possibility to incorporate other components, and a renewable surface. ${ }^{67}$ Glucose and sucrose concentrations were determined with $<3 \%$ errors with an amperometric method by using FIA technique. ${ }^{68}$ A carbon paste electrode containing GOx, HRP, and ferro- 
Table 1. Electrochemical biosensors for glucose analysis in food samples.

\begin{tabular}{|c|c|c|c|c|}
\hline Electrode modifier & $\begin{array}{c}\text { Method } \\
\text { (Potential, V) }\end{array}$ & Sensitivity & $\begin{array}{c}\text { Linear range, } M \\
\text { (Detection limit, } M \text { ) }\end{array}$ & Samples \\
\hline $\begin{array}{l}\text { GOx }+ \text { cellulose acetate } \\
\text { membrane }+\mathrm{GA}^{48}\end{array}$ & $\begin{array}{l}\text { Amp } \\
(0.65 \mathrm{~V})\end{array}$ & - & up to $3.2 \times 10^{-1}$ & orange juice, soft drinks \\
\hline $\mathrm{GOx}+\mathrm{PB}+\mathrm{GA}^{55}$ & $\begin{array}{c}\text { Amp } \\
(0.05 \mathrm{~V})\end{array}$ & $8 \mu \mathrm{A} \mathrm{mM}^{-1}$ & $\begin{array}{c}1 \times 10^{-5}-8 \times 10^{-4} \\
\left(1 \times 10^{-6}\right)\end{array}$ & wine \\
\hline GOx + PB + Nafion ${ }^{56}$ & $\begin{array}{c}\text { FIA, } \\
\text { Amp }(-0.05 \mathrm{~V})\end{array}$ & $25.13 \mathrm{nA} \mathrm{mM}^{-1}$ & $\begin{array}{c}1.5 \times 10^{-4}-2.5 \times 10^{-3} \\
\left(3 \times 10^{-5}\right)\end{array}$ & instant coffee \\
\hline $\mathrm{GOx}+\mathrm{PNR}+\mathrm{GA}^{58}$ & $\begin{array}{l}\text { Amp } \\
(-0.35 \mathrm{~V})\end{array}$ & $3.5 \mu \mathrm{A} \mathrm{mM} \mathrm{m}^{-1} \mathrm{~cm}^{-2}$ & $\begin{array}{c}9 \times 10^{-5}-1.8 \times 10^{-3} \\
\left(2.2 \times 10^{-5}\right)\end{array}$ & wine \\
\hline $\begin{array}{l}\mathrm{GDH}+\text { diaphorase }+\mathrm{CNTs}+ \\
\text { Os-polymer }+\mathrm{NAD}^{+59}\end{array}$ & $\begin{array}{l}\text { Amp } \\
(0.2 \mathrm{~V})\end{array}$ & $13.4 \mu \mathrm{A} \mathrm{mM} M^{-1} \mathrm{~cm}^{-2}$ & $\begin{array}{c}1 \times 10^{-5}-8 \times 10^{-4} \\
\left(1 \times 10^{-5}\right)\end{array}$ & sweet wine \\
\hline $\mathrm{GOx}+\mathrm{CS}^{60}$ & $\begin{array}{l}\text { Amp } \\
(0.6 \mathrm{~V})\end{array}$ & $0.0597 \mu \mathrm{A} \mathrm{mM}^{-1}$ & $\begin{array}{c}1 \times 10^{-5}-1.3 \times 10^{-1} \\
\left(5 \times 10^{-5}\right)\end{array}$ & fruit homogenates \\
\hline $\mathrm{GOx}+\mathrm{CS}^{61}$ & $\begin{array}{l}\mathrm{Amp} \\
\left(0.6 \mathrm{~V}^{*}\right)\end{array}$ & $21 \mathrm{~mA} \mathrm{M}^{-1} \mathrm{~cm}^{-2}$ & $\begin{array}{c}5 \times 10^{-5}-1.5 \times 10^{-2} \\
\left(1 \times 10^{-5}\right)\end{array}$ & $\begin{array}{l}\text { mixed fruit juice, orange } \\
\text { juice, sport drink, cola }\end{array}$ \\
\hline $\mathrm{GOx}+\mathrm{CS}+\mathrm{TiO}_{2} \mathrm{NTAs}^{62}$ & $\begin{array}{l}\text { Amp } \\
(-0.4 \mathrm{~V})\end{array}$ & $5.46 \mu \mathrm{A} \mathrm{mM} M^{-1}$ & $\begin{array}{c}0.3 \times 10^{-3}-1.5 \times 10^{-3} \\
\left(7 \times 10^{-5}\right)\end{array}$ & $\begin{array}{l}\text { soft drinks, milk, yoghurt, } \\
\text { fried tomato, ketchup }\end{array}$ \\
\hline $\begin{array}{l}\mathrm{GOx}+\operatorname{poly}\left(2,2^{\prime}-\mathrm{BT}\right)+\mathrm{BQ}^{63} \\
\mathrm{GOx}+\operatorname{poly}\left(4,4^{\prime}-\mathrm{bBT}\right)+\mathrm{BQ}^{63}\end{array}$ & $\begin{array}{c}\mathrm{Amp} \\
\left(0.4 \mathrm{~V}^{*}\right)\end{array}$ & - & $\begin{array}{c}9 \times 10^{-5}-5.2 \times 10^{-3} \\
\left(3 \times 10^{-5}\right) \\
1.5 \times 10^{-4}-5.2 \times 10^{-3} \\
\left(5 \times 10^{-5}\right)\end{array}$ & $\begin{array}{c}\text { fruit juice } \\
\text { (pear, apricot, peach) }\end{array}$ \\
\hline GOx + PB + cellulose paper ${ }^{64}$ & $\begin{array}{c}\text { Amp } \\
(-0.3 \mathrm{~V})\end{array}$ & $2.14 \mu \mathrm{A} \mathrm{mM}^{-1}$ & $\begin{array}{c}2.5 \times 10^{-4}-2 \times 10^{-3} \\
\left(1 \times 10^{-5}\right)\end{array}$ & glucose beverages \\
\hline $\begin{array}{l}\text { GOx + PEDOT + PAA + PSSLi }{ }^{65} \\
\text { GOx + PEDOT + AA + PSSH }\end{array}$ & $\begin{array}{l}\text { Amp } \\
(0.6 \mathrm{~V})\end{array}$ & $\begin{array}{l}2.74 \times 10^{-4} \mathrm{~A} \mathrm{M}^{-1} \\
2.57 \times 10^{-4} \mathrm{~A} \mathrm{M}^{-1}\end{array}$ & $\begin{array}{c}9.6 \times 10^{-4}-3 \times 10^{-2} \\
\left(2.9 \times 10^{-4}\right) \\
1.86 \times 10^{-3}-3 \times 10^{-2} \\
\left(5.6 \times 10^{-4}\right)\end{array}$ & $\begin{array}{l}\text { grape juice, } \\
\text { honey }\end{array}$ \\
\hline $\mathrm{GOx}+\mathrm{HRP}+\mathrm{Fc}^{68}$ & $\begin{array}{c}\text { FIA, } \\
\text { Amp }(0.0 \mathrm{~V})\end{array}$ & $10.7 \mathrm{nA} \mathrm{mg}^{-1} \mathrm{~L}$ & $\begin{array}{c}25-80 \mathrm{mg} \mathrm{L}^{-1} \\
-\end{array}$ & fruit juices \\
\hline GOx + CMC + ferricyanide ${ }^{69}$ & $\begin{array}{l}\text { Amp } \\
(0.4 \mathrm{~V})\end{array}$ & - & $\begin{array}{c}1 \times 10^{-3}-1 \times 10^{-1} \\
\left(1 \times 10^{-3}\right)\end{array}$ & $\begin{array}{l}\text { lactic fermenting } \\
\text { beverages }\end{array}$ \\
\hline $\mathrm{RhO}_{2}+\mathrm{GOx}+\mathrm{Nafion}^{70}$ & $\begin{array}{c}\text { Amp } \\
(-0.2 \mathrm{~V})\end{array}$ & $0.098 \mu \mathrm{A} \mathrm{mg}^{-1} \mathrm{~L}$ & $\begin{array}{c}1-250 \mathrm{mg} \mathrm{L}^{-1} \\
\left(0.2 \mathrm{mg} \mathrm{L}^{-1}\right)\end{array}$ & $\begin{array}{l}\text { instant tea, } \\
\text { honey }\end{array}$ \\
\hline $\mathrm{GOx}+\mathrm{GA}^{71}$ & $\begin{array}{l}\text { Amp } \\
(0.2 \mathrm{~V})\end{array}$ & - & $\begin{array}{c}4 \times 10^{-5}-2.5 \times 10^{-3} \\
\left(4 \times 10^{-5}\right)\end{array}$ & wine and must \\
\hline $\mathrm{GOx}+\mathrm{HMDA}+\mathrm{GA}^{72}$ & $\begin{array}{c}\text { FIA, } \\
\operatorname{Amp}(0.7 \mathrm{~V})\end{array}$ & $505 \pm 55 \mu \mathrm{A} \mathrm{mM} \mathrm{m}^{-1}$ & $\begin{array}{l}\text { up to } 1.5 \times 10^{-5} \\
\quad\left(1 \times 10^{-6}\right)\end{array}$ & $\begin{array}{l}\text { pineapple and } \\
\text { orange juice }\end{array}$ \\
\hline $\mathrm{GOx}+\mathrm{PPy}^{73}$ & $\begin{array}{l}\text { Amp } \\
(0.7 \mathrm{~V})\end{array}$ & $3.5 \mu \mathrm{A} \mathrm{mM}^{-1} \mathrm{~cm}^{-2}$ & $\begin{array}{c}5 \times 10^{-4}-2.4 \times 10^{-2} \\
\left(2.69 \times 10^{-5}\right)\end{array}$ & $\begin{array}{c}\text { fruit juices, } \\
\text { non-alcoholic beverages }\end{array}$ \\
\hline
\end{tabular}

The potential value is referred vs. $\mathrm{Ag} / \mathrm{AgCl}, 3 \mathrm{M} \mathrm{KCl}$; ${ }^{*}$ ss. saturated calomel electrode (SCE); Amp - amperometry; FIA - flow injection analysis; GOx - glucose oxidase; GDH - glucose dehydrogenase; CNTs - carbon nanotubes; NAD - nicotinamide adenine dinucleotide; GA - glutaraldehyde; PB - Prussian Blue; CS - chitosan; NTAs - nanotube arrays; PNR - poly(neutral red); HRP - horseradish peroxidase; Fc - ferrocene; PEDOT poly(3,4-ethylenedioxythiophene); PAA - polyacrylic acid; PSSLi - poly(4-lithium styrenesulphonic acid); AA - anthranilic acid; PSSH - poly(4-styrenesulphonic acid); 2,2'-BT - 2,2'-bithiophene; 4,4'-bBT - 4,4'-bis(2-methyl-3-butyn-2-ol)-2,2'-bithiophene; BQ - p-benzoquinone; CMC - carboxymethyl cellulose; HMDA - hexamethylenediamine; PPy - polypyrrole. 
cene was used in combination with the soluble enzymes invertase and mutarotase. The effect of invertase, mutarotase, and ascorbic acid on the electrode response was examined. The proposed method for glucose and sucrose measurements was validated in real samples of fruit juices.

An amperometric biosensor system based on screen-printed electrodes for simultaneously detection of glucose and L-lactate has been developed and applied for simple and rapid monitoring of their levels in lactic fermenting beverages. ${ }^{69}$ Using the proposed method, assays were completed within 5 min and a good agreement with high-performance liquid chromatography results was obtained. The system was based on three-dimensionally layered electrodes and ferricyanide as a mediator. A linear relationship between steady-state current and concentration was found over a range of $1-100 \mathrm{mM}$ (glucose) and 1-50 mM (lactate). The stability of the proposed system was examined - after storage in a freezer at temperature of $-30{ }^{\circ} \mathrm{C}$ under dry conditions, the biosensor response was stable for at least 10 months.

Table 1 summarises applications of various types of electrochemical glucose biosensors in food analysis.

In the literature, third-generation biosensors based on direct electrochemistry of GOx have been reported. ${ }^{74-79}$ These biosensors operate close to the redox potential of the enzyme, eliminating the need of redox mediator or peroxidase. The devices have significant advantages such as simpler design and independence from $\mathrm{O}_{2}$ content in the solution (the electron acts as a second substrate for the enzymatic reaction). However, analytical results for glucose detection in real food samples with third-generation biosensors are not reported yet.

\section{Amperometric Lactate Biosensors}

Lactate is a key metabolite of the anaerobic glycolytic pathway. In food industry the lactate level is an indicator of the fermentative processes and is related to the freshness, stability, and storage quality of various foods and beverages such as wine, beer, cider and diary products (milk, cheese, yoghurt, butter). In wine industry the malolactic fermentation is monitored by following the decreasing level of L-malic acid, and increasing level of L-lactic acid - conversion that leads to deacidification and softening of the wine taste. Contamination of milk, fruit juices, canned fruits/vegetables, and eggs with lactic acid bacteria during production or storage leads to increased level of L-lactate - marker of spoilage. In meat processing it can be taken as an indicator of pre-mortem stress imparting the deficiency in the meat quality.

On the other hand, L-lactic acid (E 270) is used as a preservative and food supplement; it is added as an acidulant to foods and beverages, where a tart flavour is desired (jams, jellies, candy, soft drinks, etc.) and also as emulsifying agent in bakery products. Moreover, in clinical analysis and sport medicine analysis of lactate is relevant for diagnostic of ischemic conditions and cystic fibrosis; blood lactate level correlates to the status of anaerobic metabolism during muscle work and is an indicator for training status at athletes. As an alternative to the conventional analytical methods (chromatographic and spectrophotometric) for lactate monitoring, amperometric biosensors, which provide reliable, direct and rapid measurements, are successfully used. Most of the commercial biosensors for lactate utilise lactate oxidase as a biorecognition element.

Lactate oxidase (LOx) (EC 1.13.12.4) is a globular flavoenzyme, mostly used in amperometric biosensor applications. The quantitative determination of L-lactate, using LOx, is based on the following catalytic reaction:

$$
\mathrm{L} \text {-Lactate }+\mathrm{O}_{2} \stackrel{\text { LOx }}{\longrightarrow} \text { pyruvate }+\mathrm{H}_{2} \mathrm{O}_{2}
$$

LOx catalyses the oxidation of L-lactate to pyruvate in the presence of dissolved oxygen and forms $\mathrm{H}_{2} \mathrm{O}_{2}$. The produced $\mathrm{H}_{2} \mathrm{O}_{2}$ can be reduced or oxidised electrochemically to give a current proportional to the concentration of L-lactate.

Raw milk and dairy products are among the most important foods, and their quality is of great importance for human health. Bienzyme amperometric biosensors for lactate analysis in milk and dairy products have been reported. ${ }^{80,81}$ Biosensor system, reported by Torriero et al., is based on a glassy carbon electrode with immobilised LOx and HRP with a mediator osmium redox polymer. ${ }^{80}$ The working potential of $0.0 \mathrm{~V}$ (vs. $\mathrm{Ag} / \mathrm{AgCl}, 3 \mathrm{M} \mathrm{KCl}$ ) eliminates the interference of the electroactive substances in milk samples and allows detection of extremely low lactate concentrations (5 $\mathrm{nM})$. Analysis is rapid, highly selective, and sensitive and there is a good correlation with the results obtained by standard spectrophotometric method.

L-lactic acid was determined in cow's milk, goat's milk and whey protein concentrate (WPC)-enriched goat's milk yoghurts by using an amperometric biosensor involving a bienzyme graphite-Teflon-LOx-HRP-ferrocene composite electrode. The correlation between the L-lactic acid results obtained at the same applied potential $(0.0 \mathrm{~V}$ vs. $\mathrm{Ag} / \mathrm{AgCl}$ ) using the bienzyme biosensor method and a standard colorimetric enzymatic method was 0.95 . Oneand two-way analyses of variance indicated that the biosensor method was able to discriminate between WPC supplemented and non-supplemented yoghurts, whereas this discrimination could not be accomplished with the colorimetric enzymatic method. ${ }^{81}$

To overcome interference of electroactive substances such as polyphenols and ascorbic acid, some research groups used mediators, redox polymers, and membranes, that serve as a selective barrier for easily oxidisable species: poly(5-hydroxy-1,4-naphthoquinone-co-5- hydroxy-3acetic acid-1,4-naphthoquinone), ${ }^{82}$ polyvinylimidazole-Os, ${ }^{83}$ polyaniline-co-fluoroaniline film, ${ }^{84}$ chitosan membrane with ferrocyanide, ${ }^{85}$ polysulphone membrane/ 
MWCNTs with ferrocene, ${ }^{86}$ overoxidised polypyrrole (PPYox). ${ }^{87}$

The advantages of covalent immobilisation techniques were coupled with the excellent interference-rejection capabilities of PPYox and a bilayer disposable lactate biosensor able to operate in FIA was developed by Palmisano et al.$^{87}$ The biosensing layer, obtained by glutaraldehyde co-cross-linking of LOx with bovine serum albumin (BSA), was cast on an underlying electropolymerised layer of PPYox. In this work co-cross-linking of enzyme with BSA by GA is preferred as a simple procedure mainly because it allows a higher degree of intermolecular bonding, a lower extent of enzyme crowding and enzyme deactivation, and results in an immobilised enzyme layer showing high enzyme stability and good mechanical properties. When integrated in a FIA system, a linear response up to $1 \mathrm{mM}$ and detection limit of $2 \mu \mathrm{M}$ were obtained; the introduction of a microdialysis membrane-based sampler extended the linear range up to $50 \mathrm{mM}$ lactate. The anti-interference characteristics of the biosensor permitted lactate determination in untreated milk and diluted yoghurt samples.

A similar immobilisation technique has been applied in the development of an interference and cross-talk-free dual electrode amperometric biosensor for simultaneous monitoring of glucose and lactate by FIA. ${ }^{88}$ The potential of the biosensor system was demonstrated by simultaneous determination of lactate and glucose in untreated tomato juice samples.

In order to improve the sensitivity of lactate biosensors, nanomaterials are used to increase the working surface of the electrode. Amperometric biosensors based on a gold planar electrode and two types of nanocomposites, derived from different MWCNTs, were used to determine lactate in foods (apple juice, tomato paste, olive brine, probiotic drink), in red and white wines. ${ }^{85}$ Biosensors are constructed by immobilizing LOx and HRP in a layer of chitosan onto the electrode surface and ferrocyanide was used as a mediator. The protein affinity of chitosan prevents enzyme denaturalisation, thus offering an enzyme-friendly environment. Amperometric measurements were performed at $-0.05 \mathrm{~V}$ (vs. $\mathrm{Ag} / \mathrm{AgCl}, 3 \mathrm{M} \mathrm{KCl}$ ). The linear concentration range of biosensor, based on a gold electrode, was from 5 to $244 \mu \mathrm{M}$ with a limit of detection $0.96 \mu \mathrm{M}$. The analytical system shows satisfactory stability (no loss of sensitivity after 60 consecutive measurements) and excellent stability after 15 months storage at room temperature (retained $90 \%$ of its initial sensitivity).

Bienzymatic biosensor with LOx, HRP, and redox mediator ferrocene, included in graphite-Teflon composite matrix, was developed. ${ }^{89}$ Lactate content in red wine and yoghurt was determined at potential of $0.0 \mathrm{~V}$ (vs. $\mathrm{Ag} /$ $\mathrm{AgCl}, 3 \mathrm{M} \mathrm{KCl}$ ). The composite bioelectrode exhibits longterm stability - reproducible amperometric signal was achieved with no significant loss of enzyme activity after storage for 6 months at $4{ }^{\circ} \mathrm{C}$. Detection limit of $90 \mathrm{nM}$ has been determined and excellent selectivity of analysis in real samples has been demonstrated. The sensor developed can be applied for monitoring and optimizing the fermentation process, and for controlling the quality of fermented products.

An amperometric bienzymatic biosensor based on incorporation of LOx and HRP into a CNTs/polysulphone membrane by the phase inversion technique onto screen-printed electrodes has been developed by Perez and Fabregas ${ }^{86}$ In order to improve the sensitivity and to reduce the working potential, experimental conditions are optimised and ferrocene as a redox mediator has also been incorporated into the membrane. The biosensor response time to L-lactate was $20 \mathrm{~s}$ and showed an excellent reproducibility (RSD 2.7\%); at an applied potential of $-0.1 \mathrm{~V}$ (vs. $\mathrm{Ag} / \mathrm{AgCl}$ ) the detection limit of $0.05 \mathrm{mg} \mathrm{L}^{-1} \mathrm{~L}$-lactate with a linear range from 0.1 to $5 \mathrm{mg} \mathrm{L}^{-1}$ were determined. The system has been successfully applied for quantitative detection of L-lactic acid in different wine and beer samples.

Lactate biosensors based on various types of transducers and immobilised LOx were developed, and lactate determination during fermentation process was performed in wine and must samples. ${ }^{71,90-93}$ Commercially available screen printed electrodes SensLab are preferred as transducers from research groups of Shkotova and Goriushkina. Appropriate function of the electrochemical biosensor requires effective coverage of the transducer with enzyme. In this connection, Shkotova and co-authors present two ways for immobilisation of LOx onto the working electrode surface: $1 /$ physical adsorption into a Residrol polymer layer, and $2 /$ immobilisation in poly 3,4-ethylenedioxythiophene applying electropolymerisation. ${ }^{90}$ Electrochemical measurements with both biosensor systems were performed at potential of $0.3 \mathrm{~V}$ (vs. $\mathrm{Ag} /$ $\mathrm{AgCl}$ ) in phosphate buffer, $\mathrm{pH}$ 7.2. The first type biosensor is characterised by a shorter linear dynamic range $(0.004$ $-0.5 \mathrm{mM})$ and higher sensitivity $\left(320 \mathrm{nA} \mathrm{mM}^{-1}\right)$ as compared with the second type biosensor $(0.05-1.6 \mathrm{mM}$ and sensitivity of $60 \mathrm{nA} \mathrm{mM}^{-1}$ ). The immobilisation method has been shown to have no effect on the stability and the $\mathrm{pH}$-optimum. Both biosensors are applied for analysis of lactate in wine and must. Due to their good analytical characteristics and operational stability, the use of these biosensors in wine quality control is recommended.

With same application are the amperometric biosensors based on platinum printed electrode and immobilised enzymes alcoholoxidase (AOx), GOx, and LOx, developed by Goriushkina et al. ${ }^{71}$ Their application is shown in quantitative detection of ethanol, glucose, and lactate with a linear concentration range of $0.3-20 \mathrm{mM}$ ethanol, $0.04-$ $2.5 \mathrm{mM}$ glucose, and $0.008-1 \mathrm{mM}$ lactate. The operational stability of both ethanol and glucose biosensors remains for two months, whereas for the lactate biosensor this time is only 4 days. The developed biosensors show high selectivity with respect to the substrates and have been successfully applied for the analysis of complex mixtures. 
Biosensors based on sol-gel approach are distinguished by improved activity and stability of the bioelement. One advantage of sol-gel immobilisation is that the enzyme is entrapped within the matrix without covalent bonding involved, hereby the enzyme activity is better preserved and the sensitivity of the biosensor is higher. The porous 3-D structure of sol-gel matrix favours the diffusion of substrate molecules and facilitates the specific interaction with the enzyme's active centre. A lactate biosensor with an appropriate stability, suitable for food quality control and clinical analysis (including non-invasive diagnostics), is developed on the basis of LOx immobilised in gel membranes formed from alkoxysilanes on the top of Prussian Blue modified electrode. ${ }^{93}$ Operational stability of the elaborated lactate biosensor was tested in flow-injection mode by injecting $0.1 \mathrm{mM}$ of lactate. It was found that after 500 injections the current response remained $85 \%$ of its initial value. The biosensor remained not less than $90 \%$ of its initial activity after 6 months of storage in a waterproof package at $4{ }^{\circ} \mathrm{C}$. The authors do not state data on the reproducibility of the biosensor. A main disadvantage of the sol-gel immobilisation approach is that it is not uniform - the thickness of the layer, the amount, and the distribution of loaded enzyme may vary a lot, affecting the sensor-to-sensor reproducibility.

A lactate oxidase amperometric biosensor was developed and optimised for malolactic fermentation monitoring during wine-making process. ${ }^{94} \mathrm{LOx}$ was immobilised on Prussian Blue modified screen-printed carbon electrode in order to reduce the electrochemical interferences. The biosensor showed high sensitivity $\left(852 \mu \mathrm{A} \mathrm{M}^{-1}\right)$ and a detection limit for lactic acid of $0.005 \mathrm{mM}\left(0.45 \mathrm{mg} \mathrm{L}^{-1}\right)$. The operational stability and the lifetime of the biosensor were also evaluated and were equal to $8 \mathrm{~h}$ and 30 days, respectively. In flow injection system the biosensor was used for lactic acid analysis during malolactic fermentation of a red wine and the results were compared with those obtained by ion chromatography with good agreement.

An amperometric lactate biosensor with LOx immobilised into a Prussian Blue modified electrode was fabricated..$^{95}$ The advantage of using cetyltrimethylammonium bromide (CTAB) in the electrodeposition step of PB films onto glassy carbon surfaces was confirmed taking into account both the stability and sensitivity of the measurements. The biosensor was used in the development of a FIA amperometric method for lactate determination. Under optimal conditions ( $\mathrm{pH} 6.9$ and applied potential of $-0.1 \mathrm{~V}$ vs. $\mathrm{Ag} / \mathrm{AgCl}, \mathrm{NaCl}$ sat.), the repeatability of the method for injections of $0.28 \mathrm{mM}$ lactate was $2.2 \%$ ( $\mathrm{n}=$ 18). Due to the near-zero working potential, high catalytic activity and selectivity of Prussian Blue towards the cathodic reduction of hydrogen peroxide, the biosensor system exhibited a practically interference-free response towards the target analyte. The usefulness of the developed biosensor was demonstrated by determining lactate level in beer samples and the results were in good agreement with those obtained by using a reference spectrophotometric enzyme method.

Polypyrrole (PPy) is a conductive polymer with positive charges that can be formed onto electrode surface through electropolymerisation using cyclic voltammetry. As advantages of PPy can be specified: 1/ the thickness of the PPy layer can be quantitatively controlled by controlling the number of cycles applied during cyclic voltammetry, and 2/ enzymes with negative charges can be absorbed into PPy layers via electrostatic forces. However, some authors note that the enzyme loading capability of PPy is low which may results in a reduced biosensor sensitivity. Further, PPy layer is most stable at $\mathrm{pH}$ range of 5.5 -6.0 , which limits the type of the used enzyme.

Biosensor system based on LOx, immobilised on the surface of planar electrode modified with Prussian Blue and electropolymerised polypyrrole film, was applied in quality control of kvass (traditional Russian yeast drink). ${ }^{96}$ The analytical characteristics of the resulting biosensor are as follows: a sensitivity of $190 \pm 14 \mathrm{~mA} \mathrm{M}^{-1} \mathrm{~cm}^{-2}$, a linear dynamic range from 0.5 to $500 \mu \mathrm{M}$, and high operational stability. Due to the low working potential $(0.0 \mathrm{~V}$ vs. Ag/ $\mathrm{AgCl})$ the biosensor is indifferent to species that present in the analysed samples and included in FIA system allows an express assessment of the quality of food products.

Marzouk and co-authors present an analytical FIA system by amperometric simultaneous detection of glucose and lactate. ${ }^{97}$ The enzyme-generated $\mathrm{H}_{2} \mathrm{O}_{2}$ is measured by a working platinum electrode with deposited layer of $m$-phenylenediamine. The system is applicable for quantitative analysis of glucose and lactate in dairy products.

An amperometric biosensor system based on screen-printed electrode and ferricyanide as a mediator has been used for simultaneous detection of glucose and lactate in dairy drinks. ${ }^{69}$ The linear range is from 1.0 to 100 $\mathrm{mM}$ glucose and from 1.0 to $50 \mathrm{mM}$ lactate. The duration of the analysis is only $5 \mathrm{~min}$. An excellent agreement of the results with those obtained by HPLC has also been demonstrated.

Integrated amperometric biosensors for the determination of L-malic and L-lactic acids in wine during fermentation were developed by co-immobilisation of the enzymes L-malate dehydrogenase (MDH) and diaphorase (DP), or LOx and HRP, respectively, together with the redox mediator tetrathiafulvalene (TTF), on a 3-mercaptopropionic acid (MPA) self-assembled monolayer-modified gold electrode by using a dialysis membrane. ${ }^{91}$ After 7 days of continuous use, the MDH/DP biosensor still exhibited $90 \%$ of the original sensitivity, while the LOx/HRP biosensor yielded $91 \%$ of the original response after 5 days. Calibration graphs were obtained with linear range from 0.52 to $20 \mu \mathrm{M}$ for L-malic acid, and from 0.42 to 20 $\mu \mathrm{M}$ for L-lactic acid, respectively. The experimental results obtained with both biosensors exhibited a very good correlation when plotted against those obtained by using commercial enzymatic kits. 
Rahman et al. developed an amperometric lactate biosensor based on a conducting polymer poly-5, $2^{\prime}-5^{\prime}, 2^{\prime \prime}$-terthiophene-3'-carboxylic acid (pTTCA) and MWCNTs composite on a gold electrode. ${ }^{98}$ Lactate dehydrogenase (LDH) and the oxidised form of nicotinamide adenine dinucleotide $\left(\mathrm{NAD}^{+}\right)$were subsequently immobilised onto the pTTCA/MWCNTs composite film. The detection signal was amplified by the pTTCA/MWCNTs assembly with immobilised enzyme. The applicability of the biosensor was demonstrated successfully in commercial milk and human serum samples.

Polyethyleneimine (PEI), a cationic polymer, was also used to immobilise $\mathrm{LOx}^{99}$ and $\mathrm{LDH}^{100}$ to the surface of a screen-printed carbon electrodes, which were subsequently applied to the determination of lactate in yoghurt samples. PEI possesses a strong positive charge in aqueous solutions enabling electrostatic binding of the enzymes to the electrode surface.

It should be noted that the use of charged protective layers like Nafion in design of lactate biosensors influences the response characteristics of the sensor as well, and in particular obviously reduces the sensitivity of the resulting biosensor device because the analyte is negatively charged. Such effect was observed by Patel et al. in developing of disposable-type lactate oxidase biosensors for dairy products and clinical analysis. ${ }^{99}$ It was established that the biosensor without coating of Nafion showed naturally higher response than that coated with Nafion and the current signal was dramatically attenuated by increasing the total amount of Nafion on the electrodes.

Table 2 gives an overview for applications of amperometric lactate sensors in the food analysis.

Biosensors are not only objects of fundamental and applied research but they are also important commercial products. Depending on application, the biosensor could be a laboratory stand, portable, or hand-held device. Several commercial instruments based on electrochemical amperometric biosensor are available - Fuji Electric Co. (Japan), IBA GmbH (Germany), Yellow Springs Instruments (USA), Nova Biomedical (USA), Analox Instruments (UK-USA), Sensolytics GmbH (Germany), Tectronik (Italy), BioFutura s.r.l. (Italy), Biosentec (France), and Chemel AB (Sweden) produce glucose and lactate biosensor devices applicable in bioprocess control and food analysis.

Table 2. Electrochemical biosensors for lactate analysis in food samples.

\begin{tabular}{|c|c|c|c|c|}
\hline Electrode modifier & $\begin{array}{c}\text { Method } \\
\text { (Potential, V) }\end{array}$ & Sensitivity & $\begin{array}{c}\text { Linear range, } M \\
\text { (Detection limit, } M \text { ) }\end{array}$ & Samples \\
\hline $\mathrm{LOx}+\mathrm{PB}+\mathrm{GA}^{55}$ & $\begin{array}{c}\text { Amp } \\
(0.05 \mathrm{~V})\end{array}$ & $10.4 \mu \mathrm{A} \mathrm{mM}^{-1}$ & $\begin{array}{c}1 \times 10^{-5}-5 \times 10^{-4} \\
\left(1 \times 10^{-6}\right)\end{array}$ & wine, yoghurt \\
\hline $\mathrm{LOx}+\mathrm{CMC}+$ ferricyanide $^{69}$ & $\begin{array}{c}\text { Amp } \\
(0.4 \mathrm{~V})\end{array}$ & $1.7124 \mu \mathrm{A} \mathrm{mM}^{-1}$ & $\begin{array}{c}1 \times 10^{-3}-5 \times 10^{-2} \\
\left(1 \times 10^{-3}\right)\end{array}$ & lactic fermenting beverages \\
\hline $\mathrm{LOx}_{+} \mathrm{PEDOT}^{71}$ & $\begin{array}{l}\text { Amp } \\
(0.2 \mathrm{~V})\end{array}$ & - & $\begin{array}{c}8 \times 10^{-6}-1 \times 10^{-3} \\
\left(8 \times 10^{-6}\right)\end{array}$ & wine and must \\
\hline $\mathrm{LOx}+\mathrm{HRP}+$ Os-PAA ${ }^{80}$ & $\begin{array}{c}\text { FIA, } \\
\text { Amp }(0.0 \mathrm{~V})\end{array}$ & - & $\begin{array}{c}1 \times 10^{-5}-2.5 \times 10^{-3} \\
\left(5 \times 10^{-9}\right)\end{array}$ & $\begin{array}{l}\text { fresh milk, skimmed milk, } \\
\text { acidophilus milk, skimmed } \\
\text { yoghurt, fruit yoghurt }\end{array}$ \\
\hline $\mathrm{LOx}+\mathrm{HRP}+\mathrm{Fc}^{81}$ & $\begin{array}{l}\text { Amp } \\
(0.0 \mathrm{~V})\end{array}$ & - & $\begin{array}{c}5 \times 10^{-6}-1 \times 10^{-4} \\
-\end{array}$ & yoghurts \\
\hline LOx + poly(JUG-co-JUGA $)^{82}$ & $\begin{array}{l}\text { Amp } \\
\left(-0.1 \mathrm{~V}^{*}\right)\end{array}$ & $70 \pm 10 \mu \mathrm{A} \mathrm{M}^{-1} \mathrm{~cm}^{-2}$ & $\begin{array}{c}5 \times 10^{-5}-1.5 \times 10^{-3} \\
\left(5 \times 10^{-5}\right)\end{array}$ & yoghurt \\
\hline $\mathrm{LOx}+\mathrm{HRP}+\mathrm{Fc}+\mathrm{CS}^{85}$ & $\begin{array}{l}\text { Amp } \\
(-0.05 \mathrm{~V})\end{array}$ & $3.47 \mathrm{nA} \mu \mathrm{M}^{-1}$ & $\begin{array}{c}5 \times 10^{-6}-2.44 \times 10^{-4} \\
\left(9.6 \times 10^{-7}\right)\end{array}$ & wine \\
\hline $\begin{array}{l}\mathrm{LOx}+\mathrm{HRP}+\mathrm{CNTs}+\mathrm{Fc} \\
+ \text { polysulphone membrane }{ }^{86}\end{array}$ & $\begin{array}{l}\text { Amp } \\
(-0.1 \mathrm{~V})\end{array}$ & $1168.8 \mu \mathrm{A} \mathrm{M}^{-1} \mathrm{~mm}^{-2}$ & $\begin{array}{c}1.1 \times 10^{-6}-5.6 \times 10^{-5} \\
\left(5.6 \times 10^{-7}\right)\end{array}$ & wine and beer \\
\hline $\mathrm{LOx}+\mathrm{GA}+\mathrm{BSA}+\mathrm{PPyox}^{87}$ & $\begin{array}{c}\text { FIA, } \\
\text { Amp }(0.65 \mathrm{~V})\end{array}$ & $300 \pm 10 \mathrm{nA} \mathrm{mM}^{-1} \mathrm{~L}$ & $\begin{array}{l}\text { up to } 5 \times 10^{-2} \\
\quad\left(1 \times 10^{-3}\right)\end{array}$ & untreated milk, yoghurt \\
\hline $\mathrm{LOx}+$ Resydrol $^{90}$ & & $320 \mathrm{nA} \mathrm{mM}^{-1}$ & $4 \times 10^{-6}-5 \times 10^{-4}$ & \\
\hline $\mathrm{LOx}_{+} \mathrm{PEDOT}^{90}$ & $\begin{array}{l}\text { Amp } \\
(0.3 \mathrm{~V})\end{array}$ & $60 \mathrm{nA} \mathrm{mM}^{-1}$ & $\begin{array}{c}- \\
5 \times 10^{-5}-1.6 \times 10^{-3} \\
-\end{array}$ & $\begin{array}{l}\text { wine, } \\
\text { must }\end{array}$ \\
\hline $\mathrm{LOx}+\mathrm{HRP}+\mathrm{TTF}+\mathrm{MPA}^{91}$ & $\begin{array}{l}\text { Amp } \\
(-0.05 \mathrm{~V})\end{array}$ & $2711 \pm 190 \mu \mathrm{A} \mathrm{M}^{-1}$ & $\begin{array}{c}4.2 \times 10^{-7}-2 \times 10^{-5} \\
\left(4.2 \times 10^{-7}\right)\end{array}$ & wine \\
\hline
\end{tabular}




\begin{tabular}{|c|c|c|c|c|}
\hline $\mathrm{LOx}+\mathrm{APTS}+\mathrm{PB}^{93}$ & $\begin{array}{c}\text { FIA, } \\
\text { Amp }(0.0 \mathrm{~V})\end{array}$ & $0.18 \mathrm{~A} \mathrm{M}^{-1} \mathrm{~cm}^{-2}$ & $\begin{array}{c}5 \times 10^{-7}-1 \times 10^{-3} \\
\left(1 \times 10^{-7}\right)\end{array}$ & beverages \\
\hline $\mathrm{LOx}+\mathrm{PB}+\mathrm{CTAB}^{95}$ & $\begin{array}{c}\text { FIA, } \\
\operatorname{Amp}(-0.1 \mathrm{~V})\end{array}$ & - & $\begin{array}{c}4 \times 10^{-6}-2.8 \times 10^{-4} \\
\left(8.4 \times 10^{-7}\right)\end{array}$ & beer \\
\hline $\mathrm{LOx}+\mathrm{PPy}+\mathrm{PB}^{96}$ & $\begin{array}{l}\text { Amp } \\
(0.0 \mathrm{~V})\end{array}$ & $190 \pm 14 \mathrm{~mA} \mathrm{M}^{-1} \mathrm{~cm}^{-2}$ & $\begin{array}{c}5 \times 10^{-7}-5 \times 10^{-4} \\
\left(5 \times 10^{-7}\right)\end{array}$ & kvass \\
\hline $\mathrm{LDH}+$ pTTCA + MWCNTs $+\mathrm{NAD}^{+98}$ & $\begin{array}{c}\text { Amp } \\
(0.3 \mathrm{~V})\end{array}$ & $0.0106 \mu \mathrm{A} \mu \mathrm{M}^{-1}$ & $\begin{array}{c}5 \times 10^{-6}-9 \times 10^{-5} \\
\left(1 \times 10^{-6}\right)\end{array}$ & milk \\
\hline LOx + PEI + PCS + Nafion ${ }^{99}$ & $\begin{array}{l}\text { Amp } \\
(0.6 \mathrm{~V})\end{array}$ & $0.682 \mathrm{nA} \mu \mathrm{M}^{-1}$ & $\begin{array}{l}\text { up to } 1 \times 10^{-3} \\
\quad\left(5 \times 10^{-7}\right)\end{array}$ & yoghurt, buttermilk \\
\hline LOx + PtNPs + GCNF + PEI + GA $^{100}$ & $\begin{array}{c}\text { Amp } \\
(0.3 \mathrm{~V})\end{array}$ & $41.3 \mu \mathrm{A} \mathrm{M}^{-1} \mathrm{~cm}^{-2}$ & $\begin{array}{c}1 \times 10^{-5}-2 \times 10^{-3} \\
\quad\left(6.9 \times 10^{-6}\right)\end{array}$ & wine, cider \\
\hline LOx + laponite-organosilasesquioxane & $\mathrm{e}^{101} \mathrm{Amp}$ & $0.33 \pm 0.01 \mathrm{~A} \mathrm{M}^{-1} \mathrm{~cm}^{-2}$ & $\begin{array}{c}3 \times 10^{-6}-3 \times 10^{-4} \\
\left(1 \times 10^{-6}\right)\end{array}$ & $\begin{array}{l}\text { yoghurt, fermented milk, } \\
\text { red wine }\end{array}$ \\
\hline $\mathrm{LOx}+$ laponite/CS hydrogels $+\mathrm{FcMe}^{10}$ & $02 \quad \begin{array}{c}\text { Amp } \\
(0.4 \mathrm{~V})\end{array}$ & $0.326 \pm 0.003 \mathrm{~A} \mathrm{M}^{-1} \mathrm{~cm}^{-2}$ & $\begin{array}{l}1 \times 10^{-5}-7 \times 10^{-4} \\
\quad\left(3.8 \times 10^{-6}\right)\end{array}$ & $\begin{array}{l}\text { white wine, } \\
\text { fermented milk, beer }\end{array}$ \\
\hline LOx (SIRE-technology) ${ }^{103}$ & $\begin{array}{l}\text { Amp } \\
(0.65 \mathrm{~V})\end{array}$ & - & $\begin{array}{l}\text { up to } 1 \times 10^{-4} \\
\left(3.3 \times 10^{-5}\right)\end{array}$ & tomato paste, baby food \\
\hline $\mathrm{LDH}+\mathrm{PyrOx}^{104}$ & $\begin{array}{c}\text { EIS } \\
(0.0 \mathrm{~V})\end{array}$ & - & $\begin{array}{l}1 \times 10^{-5}-2.5 \times 10^{-4} \\
\quad\left(1.7 \times 10^{-5}\right)\end{array}$ & yoghurt \\
\hline $\mathrm{LOx}+\mathrm{HRP}+\mathrm{PPy}^{105}$ & $\begin{array}{l}\text { Amp } \\
(0.075 \mathrm{~V})\end{array}$ & $13500 \pm 600 \mu \mathrm{A} \mathrm{M}^{-1} \mathrm{~cm}^{-2}$ & $\begin{array}{l}1 \times 10^{-6}-1 \times 10^{-4} \\
\quad\left(5.2 \times 10^{-7}\right)\end{array}$ & red wine \\
\hline $\mathrm{LOx}+$ natural protein membrane $\mathrm{e}^{106}$ & $\begin{array}{c}\text { FIA, } \\
\text { Amp }(0.59 \mathrm{~V})\end{array}$ & $81.2 \mu \mathrm{A} \mathrm{mM}^{-1}$ & $\begin{array}{c}1 \times 10^{-4}-1 \times 10^{-3} \\
\left(5 \times 10^{-5}\right)\end{array}$ & milk, cheese, kefir \\
\hline $\mathrm{LOx}+\mathrm{HRP}^{107}$ & $\begin{array}{l}\text { Amp } \\
(0.0 \mathrm{~V})\end{array}$ & $0.84 \mathrm{nA} \mu \mathrm{M}^{-1} \mathrm{~L}$ & $\begin{array}{c}1 \times 10^{-5}-1.8 \times 10^{-4} \\
\left(1 \times 10^{-5}\right)\end{array}$ & yoghurt, cheese, milk \\
\hline LDH + SWCNTs + VB + Nafion ${ }^{108}$ & $\begin{array}{l}\text { Amp } \\
(0.2 \mathrm{~V})\end{array}$ & - & $\begin{array}{c}2 \times 10^{-4}-1 \times 10^{-3} \\
-\end{array}$ & probiotic yoghurt \\
\hline LOx + DTSP ${ }^{109}$ & $\underset{\left(0.3 \mathrm{~V}^{*}\right)}{\mathrm{Amp}}$ & $0.77 \pm 0.08 \mu \mathrm{A} \mathrm{mM}{ }^{-1}$ & $\begin{array}{l}\text { up to } 3 \times 10^{-4} \\
\quad\left(1 \times 10^{-5}\right)\end{array}$ & wine, beer \\
\hline $\mathrm{LOx}+\mathrm{MnO}_{2}+$ nanoCoPc${ }^{110}$ & $\begin{array}{c}\text { Amp } \\
\left(0.5 \mathrm{~V}^{*}\right)\end{array}$ & $3.98 \mu \mathrm{A} \mathrm{mM}^{-1} \mathrm{~cm}^{-2}$ & $\begin{array}{c}2 \times 10^{-5}-4 \times 10^{-3} \\
-\end{array}$ & milk \\
\hline LOx + 3,4DHS-AuNPs ${ }^{111}$ & $\begin{array}{c}\mathrm{Amp} \\
\left(0.3 \mathrm{~V}^{* *}\right)\end{array}$ & $5.1 \pm 0.1 \mu \mathrm{A} \mathrm{mM} M^{-1}$ & $\begin{array}{l}\text { up to } 8 \times 10^{-4} \\
\left(2.6 \times 10^{-6}\right)\end{array}$ & wine, beer, yoghurt \\
\hline $\mathrm{LOx}+\mathrm{PB}^{112}$ & $\begin{array}{l}\text { Amp } \\
(0.0 \mathrm{~V})\end{array}$ & $11.7 \pm 0.5 \mathrm{nA} \mathrm{mM}^{-1}$ & $\begin{array}{l}\text { up to } 5 \times 10^{-2} \\
\quad\left(1 \times 10^{-3}\right)\end{array}$ & fermented milk products \\
\hline $\mathrm{LDH}+\mathrm{GONPs}^{113}$ & $\begin{array}{l}\text { Amp } \\
(0.7 \mathrm{~V})\end{array}$ & - & $\begin{array}{c}5 \times 10^{-3}-5 \times 10^{-2} \\
\left(1 \times 10^{-7}\right)\end{array}$ & $\begin{array}{l}\text { beer, wine, milk, curd, } \\
\text { yoghurt }\end{array}$ \\
\hline $\mathrm{LOx}+\mathrm{DNPs}+\mathrm{MPTS}+\mathrm{HMF}^{114}$ & $\mathrm{CV}$ & $2.6 \mu \mathrm{A} \mathrm{mM} M^{-1}$ & $\begin{aligned} 5.3 \times 10^{-5}-1.6 \times 10^{-3} \\
\left(1.6 \times 10^{-5}\right)\end{aligned}$ & wine \\
\hline
\end{tabular}

BSA - bovine serum albumin; PPyox - overoxidised polypyrrole; EIS - electrochemical impedance spectroscopy; LOx - lactate oxidase; LDH - lactate dehydrogenase; FcMe - ferrocene-methanol; TTF - tetrathiafulvalene; MPA - 3-mercaptopropionic acid; CTAB - cetyltrimethylammonium bromide; CMC - carboxymethyl cellulose; Os-PAA - [Os(bpy)2ClPyCH2NHpoly(allylamine)]; poly(JUG-co-JUGA) - poly(5-hydroxy-1,4-naphthoquinone-co-5-hydroxy-3-thioacetic acid-1,4-naphthoquinone); PEI - polyethyleneimine; PCS - poly(carbamoyl)sulphonate hydrogel; pTTCA - poly-5,2'-5',2"-terthiophene-3'-carboxylic acid; MWCNTs - multi-wall carbon nanotubes; SIRE - sensors based on injection of the recognition element; PyrOx - pyruvate oxidase; NPs - nanoparticles; GCNF - graphitised carbon nanofibers; APTS - $\gamma$-aminopropyl triethoxysiloxane; SWCNTs - single-wall carbon nanotubes; VB - Variamine Blue; DTSP - 3,3'-dithiodipropionic acid di( $N$-succinimidyl ester); CoPc - cobalt phthalocyanine; GO - graphene oxide; DNPs - diamond nanoparticles; MPTS - (3-mercaptopropyl)-trimethoxysilane; HMF - hydroxymethyl-ferrocene; ${ }^{* *}$ vs. silver pseudoreference electrode. Other abbreviations are the same as Table 1. 


\section{Conclusions and Perspectives}

Over the two last decades phenomenal growth has been observed in the field of electrochemical biosensors for analysis of food and beverages. Amperometric enzyme-based biosensors have been developed and widely used due to their well-understood bio-interaction and detection process. The high affinity of the enzyme molecules for their target analytes allowed the development of extremely sensitive and selective biosensor systems applicable in complex and variable samples. In electrochemical biosensor design precise selection of the enzyme type, suitable working electrode, as well as suitable, robust, and reproducible immobilisation methodology play a crucial role in order to achieve better selectivity and stability of biosensors. This brief review has highlighted the strategies that have been introduced to successfully improve the operational parameters of amperometric enzyme-based biosensors for glucose and lactate detection in food samples. The analytical performances in terms of high sensitivity, wide linear range and low detection limit of some of the reviewed biosensors evidence that these systems have the potential to radically change food analysis. However, despite the variety of electrochemical biosensors for glucose and lactate monitoring, ${ }^{35,115-125}$ limited number of devices successfully applied for quality and safety assessment of foods and beverages testifies that the food sample matrices present significant challenges and there is still a need to improve analytical performances, both selectivity and operational stability of the immobilised biocomponent and shelf-life of biosensor systems. Moreover, designing novel reliable and commercially available biosensors that are capable to detect nanomolar levels of analytes, as well as biosensors for reliable analysis of multiple analytes using a single device, ${ }^{126,127}$ are required in the field of food industry and have become an important topic in electroanalysis.

Electrochemical biosensors offer the possibility of rapid and on-site monitoring, thus providing real-time information essential in the control of production processes. The great advantage of real-time monitoring in food manufacture, particularly of dairy and winemaking industries, will motivate the commercialisation and widespread usage of these devices. Generally, the driving force for commercialisation of biosensor systems is the market/hand-held size, simplicity of operation and the instrument cost. Transforming electrochemical biosensor system into a simple, easy-to-use, cheap and portable commercial product from lab-scale research is complicated and still remains a challenge due to its high cost, stability issues, and complex instrumentation design. The fabrication of hand-held biosensor devices can be complex due to the difficulty in ensuring the operational stability and reproducibility of the sensor; in most cases the stability of the enzyme immobilised on the electrode surface is not maintained in real sample analysis conditions. It should also be taken into account that the sophisticated sensing device fabrication also may incur more cost which affects its commercialisation.
Current trends toward miniaturisation of biosensor systems have led researchers to use screen-printed electrodes (SPE). The printing of electrodes is one of the most promising technologies in transducers elaboration because it is economic, enables easy integration, improves portability, and drastically reduces contamination. Screen-printing technology is well established, reproducible, and easily incorporated in miniaturised portable devices, so SPEs belong to the most suitable electrodes for biosensing purposes. SPEs can be modified in the same way as conventional electrodes through surface chemistry modification or directly modifying the composition of the ink. Moreover, with the discovery of new nano-sized materials with superior electrocatalytic properties, we expect research groups to explore novel advanced SPEs.

Development of sensor networks and wireless signal transmitters for remote sensing is relevant in the field of biosensor technologies. Nowadays, fabrication of portable potentiostats is not a scientific challenge. In fact, small (pocket size) portable potentiostats powered by a USB connection, combined with a simple notepad, and conveniently designed to fit SPEs for on-field use, are available in the electrochemical equipment market. Particularly, for mobile sensor/biosensor applications several companies offer potentiostats with integrated Bluetooth, using a smartphone for control. Such portable potentiostat with wireless connectivity to smartphones would facilitate analysis at the point-of-use and in the field, where access to a computer is impossible.

Future trend in biosensors engineering is development of "smart" sensors which are capable of measuring, analysing, and adjusting the appropriate parameters of the analyte. The potential of this technology is enormous and should revolutionise analysis and control, because it will not only improve the food quality/safety, but will also provide much more effective control with less employment, time and energy saving.

\section{References}

1. C. Ozdemir, F. Yeni, D. Odaci, S. Timur, Food Chem. 2010, 119, 380-385. DOI:10.1016/j.foodchem.2009.05.087

2. G. Xu, M. Zhang, X. Yu, Acta Chim. Slov. 2018, 65, 502-511. DOI:10.17344/acsi.2017.3974

3. S. Malhotra, Y. Tang, P. Varshney, Acta Chim. Slov. 2018, 65, 687-697. DOI:10.17344/acsi.2018.4386

4. D. Durovic, B. Milisavljevic, M. Nedovic-Vukovic, B. Potkonjak, S. Spasic, M. Vrvic, Acta Chim. Slov. 2017, 64, 276-282. DOI:10.17344/acsi.2016.2582

5. G. Nikoleli, D. Nikolelis, C. Siontorou, S. Karapetis, T. Varzakas, Adv. Food Nutr. Res. 2018, 84, 57-102.

DOI:10.1016/bs.afnr.2018.01.003

6. J. Kos, E. Hajnal, I. Jajic, S. Krstovic, J. Mastilovic, B. Saric, P. Jovanov, Acta Chim. Slov. 2016, 63, 747-756.

DOI:10.17344/acsi.2016.2451 
7. J. Vichapong, Y. Santaladchaiyakit, R. Burakham, S. Srijaranai, Acta Chim. Slov. 2017, 64, 590-597.

DOI:10.17344/acsi.2017.3336

8. N. Temel1, R. Gurkan, Acta Chim. Slov. 2018, 65, 138-149. DOI:10.17344/acsi.2017.3724

9. Y. Santaladchaiyakit, J. Bunchamnan, D. Tongsa, S. Srijaranai, Acta Chim. Slov. 2017, 64, 849-857.

DOI:10.17344/acsi.2017.3413

10. R. Pilolli, L. Monaci, A. Visconti, TRAC Trends Analyt. Chem. 2013, 47, 12-26. DOI:10.1016/j.trac.2013.02.005

11. X. Lu (Ed.): Sensing Techniques for Food Safety and Quality Control, Royal Society of Chemistry, 2017, pp. 1-358. DOI:10.1039/9781788010528

12. M. Mutlu, Biosensors in Food Processing, Safety, and Quality Control, CRC Press, New York, USA, 2017, pp. 1-385. ISBN 9781138116009

13. D. Correa, A. Pavinatto, L. Mercante, L. Mattoso, J. Oliveira, A. Riul Jr, in: A. Grumezesco (Ed.): Nanobiosensors, Elsevier, Amsterdam, Netherlands, 2016, pp. 205-244.

DOI:10.1016/B978-0-12-804301-1.00006-0

14. A. Cifuentes, ISRN Anal. Chem. 2012, Article ID 801607, 16 pages. DOI:10.5402/2012/801607

15. G. Bülbül, A. Hayat, S. Andreescu, Sensors, 2015, 15, 3073630758. DOI: $10.3390 / \mathrm{s} 151229826$

16. C. Adley, Foods 2014, 3, 491-510. DOI:10.3390/foods3030491

17. H. Malekzad, P. Zangabad, H. Mirshekari, M. Karimi, M. Hamblin, Nanotechnol. Rev. 2016, 6, 301-329.

DOI:10.1515/ntrev-2016-0014

18. J. Wang, Microchim. Acta 2012, 177, 245-270. DOI:10.1007/s00604-011-0758-1

19. P. Solanki, A. Kaushik, V. Agrawal, B. Malhotra, NPG Asia Mater. 2011, 3, 17-24. DOI:10.1038/asiamat.2010.137

20. M. Holzinger, A. Le Goff, S. Cosnier, Front. Chem. 2014, 2, 63 (10 pages). DOI:10.3389/fchem.2014.00063

21. S. Alim, J. Vejayan, M. Yusoff, A. Kafi, Biosens. Bioelectron. 2018, 121, 125-136. DOI:10.1016/j.bios.2018.08.051

22. Z. Zhu, Nano-Micro Lett. 2017, 9, 25 (24 pages). DOI:10.1007/s40820-017-0128-6

23. A. Lawal, Biosens. Bioelectron. 2018, 106, 149-178. DOI:10.1016/j.bios.2018.01.030

24. C. Justino, A. Gomes, A. Freitas, A. Duarte, T. Rocha-Santos, TrAC Trends Anal. Chem. 2017, 91, 53-66.

DOI:10.1016/j.trac.2017.04.003

25. P. Suvarnaphaet, S. Pechprasarn, Sensors 2017, 17, 2161 (24 pages). DOI:10.3390/s17102161

26. Y. Shao, J. Wang, H. Wu, J. Liu, I. A. Aksay, Y. Lin, Electroanalysis 2010, 22, 1027-1036. DOI:10.1002/elan.200900571

27. M. Zhou, Y. Zhai, S. Dong, Anal. Chem. 2009, 81, 5603-5613. DOI:10.1021/ac900136z

28. H. Li, S. Liu, Z. Dai, J. Bao, X. Yang, Sensors 2009, 9, 85478561. DOI:10.3390/s91108547

29. W. Feng, P. Ji, Biotechnol. Adv. 2011, 29, 889-895. DOI:10.1016/j.biotechadv.2011.07.007

30. B. Perez-Lopez, A. Merkoci, Trends Food Sci. Technol. 2011, 22, 625-639. DOI:10.1016/j.tifs.2011.04.001
31. L. Mello, L. Kubota, Food Chem. 2002, 77, 237-256. DOI:10.1016/S0308-8146(02)00104-8

32. W. Putzbach, N. Ronkainen, Sensors (Basel). 2013, 13, 48114840. DOI:10.3390/s130404811

33. K. Warriner, S. Reddy, A. Namvar, S. Neethirajan, Trends Food Sci. Technol. 2014, 40, 183-199.

DOI:10.1016/j.tifs.2014.07.008

34. Y Zeng, Z. Zhu, D. Du, Y. Lin, J. Electroanal. Chem. 2016, 781, 147-154. DOI:10.1016/j.jelechem.2016.10.030

35. C. Chen, Q. Xie, D. Yang, H. Xiao, Y. Fu, Y. Tan, S. Yao, RSC Adv. 2013, 3, 4473-4491. DOI:10.1039/c2ra22351a

36. V. Scognamiglio, Biosens. Bioelectron. 2013, 47, 12-25. DOI:10.1016/j.bios.2013.02.043

37. A. Hayat, G. Catanante, J. L. Marty, Sensors 2014, 14, 23439 23461. DOI: $10.3390 / \mathrm{s} 141223439$

38 A. Sassolas, J. Blum, B. Leca-Bouvier, Biotechnol. Adv. 2011, 30, 489-511. DOI:10.1016/j.biotechadv.2011.09.003

39. N. Demirkıran, E. Ekinci, Acta Chim. Slov. 2012, 59, 302-306. http://acta-arhiv.chem-soc.si/59/59-2-302.pdf

40. R. Săndulescu, M. Tertiş, C. Cristea, E. Bodoki, in: T. Rinken (Ed.): Biosensors - Micro and Nanoscale Applications, IntechOpen, London, UK, 2015.

DOI:10.5772/60510. Available from: https://www. intechopen.com/books/biosensors-micro-and-nanoscaleapplications/new- materials-for-the-construction-ofelectrochemical-biosensors

41. N. Ronkainen, H. Halsall, W. Heineman, Chem. Soc. Rev. 2010, 39, 1747-1763. DOI:10.1039/b714449k

42. H. Schnerr, in: R. Marks, D. Cullen, I. Karube, C. Lowe, H. Weetall (Ed.): Handbook of Biosensors and Biochips, Part Eight Biosensor Applications, John Wiley \& Sons, Ltd., USA, 2008. DOI:10.1002/9780470061565.hbb118

43. M. Thakur, K. Ragavan, J. Food Sci. Technol. 2013, 50, 625641. DOI:10.1007/s13197-012-0783-z

44. E. Korotkaya, Foods and Raw Mater. 2014, 2, 161-171. DOI:10.12737/5476

45. World Health Organization. Diabetes, http://www.who.int/news-room/fact-sheets/detail/ diabetespp, (assessed: October 30, 2018)

46. S. Bogdanov, P. Martin, Swiss Bee Research Centre 2002, 1-20. http://www.bee-hexagon.net/files/file/fileE/Honey/ AuthenticityRevue_Internet.pdf

47. G. Rapeanu, C. Vicol, C. Bichescu, Innov. Rom. Food Biotechnol. 2009, 5, 1-9. http://www.bioaliment.ugal.ro/revista...

48. B. Alp, S. Multu, M. Mutlu, Food Res. Int. 2000, 33, 107-112. DOI:10.1016/S0963-9969(00)00013-2

49. T. Dodevska, E. Horozova, N. Dimcheva, Anal. Bioanal. Chem. 2006, 386, 1413-1418.

DOI:10.1007/s00216-006-0682-0

50. E. Horozova, T. Dodevska, N. Dimcheva, Bioelectrochemistry 2009, 74, 260-264.

DOI:10.1016/j.bioelechem.2008.09.003

51. E. Horozova, T. Dodevska, N. Dimcheva, R. Mussarlieva, Int. J. Electrochem. Sci. 2011, Article ID 697698, 8 pages. DOI:10.4061/2011/697698 
52. E. Horozova, T. Dodevska, N. Dimcheva, J. Chem. Technol. Metall. 2008, 43, 59-64.

http://dl.uctm.edu/journal/node/j2008-1/8_Horozova_ Dodevska-59-64.pdf

53. T. Dodevska, E. Horozova, N. Dimcheva, Cent. Eur. J. Chem. 2010, 8, 19-27. DOI:10.2478/s11532-009-0102-3

54. A. Karyakin, Electroanalysis 2001, 13, 813-819. DOI:10.1002/1521-4109(200106)13:10<813::AID-

\section{ELAN813>3.0.CO;2-Z}

55. S. de Luca, M. Florescu, M. Ghica, A. Lupu, G. Palleschi, C. Brett, D. Compagnone, Talanta 2005, 68, 171-178.

DOI:10.1016/j.talanta.2005.06.017

56. I. de Mattos, M. Areias, Talanta 2005, 66, 1281-1286. DOI:10.1016/j.talanta.2005.01.044

57. M. Ghica, C. Brett, Anal. Lett. 2005, 38, 907-920. DOI:10.1081/AL-200054036

58. M. Ghica, C. Brett, Electroanalysis 2006, 18, 748-756. DOI:10.1002/elan.200503468

59. R. Antiochia, L. Gorton, Biosens. Bioelectron. 2007, 22, 26112617. DOI:10.1016/j.bios.2006.10.023

60. L. Ang, L. Por, M. Yam, PLoS ONE 2015, 10, e0111859. DOI:10.1371/journal.pone.0111859

61. M. Yang, Y. Yang, B. Liu, G. Shen, R. Yu, Sens. Actuat. B Chem. 2004, 101, 269-276. DOI:10.1016/j.snb.2004.01.003

62. M. Artigues, J. Abella, S. Colominas, Sensors 2017, 17, 2620 2635 DOI:10.3390/s17112620

63. M. Pilo, R. Farre, J. Lachowicz, E. Masolo, A. Panzanelli, G. Sanna, N. Senes, A. Sobral, N. Spano, J. Anal. Methods Chem. 2018, Article ID 1849439, 7 pages DOI:10.1155/2018/1849439

64. N. Sekar, S. Mousavi, S. Sum, H. Ng, L. Ge, S. Tan, Sens. Actuat. B Chem. 2014, 204, 414-420.

DOI:10.1016/j.snb.2014.07.103

65. P. Krzyczmonik, E. Socha, S. Skrzypek, Electrocatalysis 2018, 9, 380-387. DOI:10.1007/s12678-017-0442-2

66. H. Yildiz, S. Kiralp, L. Toppare, Y. Yagci, Int. J. Biol. Macromol. 2005, 37, 174-178. DOI:10.1016/j.ijbiomac.2005.10.004

67. P. Erden, S. Pekyardımc1, E. Kılıç, Acta Chim. Slov. 2012, 59, 824-832. http://acta-arhiv.chem-soc.si/59/59-4-824.pdf

68. Y. Guemas, M. Boujtita, N. El Murr, Appl. Biochem. Biotechnol. 2000, 89, 171-181. DOI:10.1385/ABAB:89:2-3:171

69. N. Sato, H. Okuma, Anal. Chim. Acta 2006, 565, 250-254. DOI:10.1016/j.aca.2006.02.041

70. P. Kotzian, P. Brazdilova, S. Rezkova, K. Kalcher, K. Vytras, Electroanalysis 2006, 18, 1499-1504.

DOI:10.1002/elan.200503549

71. T. Goriushkina, A. Soldatkin, S. Dzyadevych, J. Agric. Food Chem. 2009, 57, 6528-6535. DOI:10.1021/jf9009087

72. M. Portaccio, M. Lepore, J. Sensors 2017, Article ID 7498945, 8 pages. DOI:10.1155/2017/7498945

73. J. Ayenimo, S. Adeloju, Food Chem. 2017, 229, 127-135. DOI:10.1016/j.foodchem.2017.01.138

74. Y. Wang, L. Liu, M. Li, S. Xu, F. Gao, Biosens. Bioelectron. 2011, 30, 107-111. DOI:10.1016/j.bios.2011.08.038

75. J. Li, Z. Yang, Y. Tang, Y. Zhang, X. Hu, Biosens. Bioelectron. 2013, 41, 698-703. DOI:10.1016/j.bios.2012.09.059
76. Y. Bai, T. Xu, J. Luong, H. Cui, Anal. Chem. 2014, 86, 49104918. DOI:10.1021/ac501143e

77. M. Wooten, S. Karra, M. Zhang, W. Gorski, Anal. Chem. 2014, 86, 752-757. DOI:10.1021/ac403250w

78. S. Su, H. Sun, F. Xu, L. Yuwen, C. Fan, L. Wang, Microchim. Acta 2014, 181, 1497-1503.

DOI:10.1007/s00604-014-1178-9

79. N. Ridhuan, K. Razak, Z. Lockman, Sci. Rep. 2018, 8, Article number: 13722. DOI:10.1038/s41598-018-32127-5

80. A. Torriero, E. Salinas, F. Battaglini, J. Raba, Anal. Chim. Acta 2003, 498, 155-163. DOI:10.1016/S0003-2670(03)00897-3

81. A. Herrero, T. Requena, A. Reviejo, J. Pingarrón, Eur. Food Res. Technol. 2004, 219, 557-560.

DOI:10.1007/s00217-004-0973-7

82. J. Haccoun, B. Piro, V. Noe, M. Pham, Bioelectrochemistry 2006, 68, 218-226. DOI:10.1016/j.bioelechem.2005.09.001

83. X. Li, J. Zang, Y. Liu, Z. Lu, Q. Li, C. Li, Anal. Chim. Acta 2013, 771, 102-107. DOI:10.1016/j.aca.2013.02.011

84. S. Suman, R. Singhal, A. Sharma, B. Malthotra, C. Pundir, Sens. Actuat. B Chem. 2005, 107, 768-772.

DOI:10.1016/j.snb.2004.12.016

85. R. Monosik, M. Stredansky, G. Greif, E. Sturdik, Food Control 2012, 23, 238-244. DOI:10.1016/j.foodcont.2011.07.021

86. S. Perez, E. Fabregas, Analyst 2012, 137, 3854-3861. DOI:10.1039/c2an35227c

87. F. Palmisano, M. Quinto, R. Rizzi, P. Zambonin, Analyst 2001, 126, 866-870. DOI:10.1039/b010180j

88. F. Palmisano, R. Rizzi, D. Centonze, P. Zambonin, Biosens. Bioelectron. 2000, 15, 531-539.

DOI:10.1016/S0956-5663(00)00107-X

89. B. Serra, A. Reviejo, C. Parrado, J. Pingarron, Biosens. Bioelectron. 1999, 14, 505-513.

DOI:10.1016/S0956-5663(99)00022-6

90. L. Shkotova, T. Goriushkina, C. Tran-Minh, J. Chovelon, A. Soldatkin, S. Dzyadevych, Mater. Sci. Eng. C 2008, 5-6, $943-$ 948. DOI:10.1016/j.msec.2007.10.038

91. M. Gamella, S. Campuzano, F. Conzuelo, J. Curiel, R. Munos, A. Reviejo, J. Pingarrón, Talanta 2010, 81, 925-933. DOI:10.1016/j.talanta.2010.01.038

92. M. Albareda-Sirvent, A. Hart, Sens. Actuators B Chem. 2002, 87, 73-81. DOI:10.1016/S0925-4005(02)00219-8

93. E. Yashina, A. Borisova, E. Karyakina, O. Shchegolikhina, M. Vagin, D. Sakharov, A. Tonevitsky, A. Karyakin, Lett. Anal. Chem. 2010, 82, 1601-1604. DOI:10.1021/ac9027615

94. A. Sannini, D. Albanese, F. Malvano, A. Crescitelli, M. Di Matteo, Chem. Eng. Trans. 2015, 44, 283-288.

DOI:10.3303/CET1544048

95. D. Lowinsohn, M. Bertotti, J. Brazil. Chem. Soc. 2008, 19, 637-642. DOI:10.1590/S0103-50532008000400005

96. L. Korneyeva, A. Borisova, Y. Yashina, E. Karyakina, O. Voronin, S. Cosnier, A. Karyakin, Mosc. Univ. Chem. Bull. 2010, 65, 49-55. DOI:10.3103/S0027131410010074

97. S. Marzouk, H. Sayour, A. Ragab, W. Cascio, S. Hassan, Electroanalysis 2000, 12, 1304-1311.

DOI:10.1002/1521-4109(200011)12:16<1304::AIDELAN1304>3.0.CO;2-B 
98. M. Rahman, M. Shiddiky, M. Rahman, Y. Shim, Anal. Biochem. 2009, 384, 159-165. DOI:10.1016/j.ab.2008.09.030

99. N. Patel, A. Erlenkotter, K. Cammann, G. Chemnitius, Sens. Actuat. B Chem. 2000, 67, 134-141.

DOI:10.1016/S0925-4005(00)00410-X

100. O. Loaiza, P. Lamas-Ardisana, L. Añorga, E. Jubete, V. Ruiz, M. Borghei, G. Cabañero, H. Grande, Bioelectrochemistry 2015, 101, 58-65. DOI:10.1016/j.bioelechem.2014.07.005

101. V. Zanini, B. Mishima, P. Labbe, V. Solis, Electroanalysis 2010, 22, 946-954. DOI:10.1002/elan.200900416

102. V. Zanini, B. Mishima M. Solis, Sens. Actuat. B Chem. 2011, 155, 75-80. DOI:10.1016/j.snb.2010.11.026

103. K. Kriz, L. Kraft, M. Krook, D. Kriz, J. Agric. Food Chem. 2002, 50, 3419-3424. DOI:10.1021/jf0114942

104. D. Chan, M. Barsan, Y. Korpan, C. Brett, Electrochim. Acta 2017, 231, 209-215. DOI:10.1016/j.electacta.2017.02.050

105. P. Gimenez-Gomez, M. Gutierrez-Capitan, F. Capdevila, A. Puig-Pujol, C. Fernandez-Sanchez, C. Jimenez-Jorquera, Anal. Chim. Acta 2016, 905, 126-133.

DOI:10.1016/j.aca.2015.11.032

106. Z. Bori, G. Csiffáry, D. Virág, M. Tóth-Markus, A. Kiss, N. Adányi, Electroanalysis 2012, 24, 158-164.

DOI:10.1002/elan.201100409

107. F. Ghamouss, S. Ledru, N. Ruillé, F. Lantier, M. Boujtita, Anal. Chim. Acta 2006, 570, 158-164.

DOI:10.1016/j.aca.2006.04.022

108. A. Radoi, D. Moscone, G. Palleschi, Anal. Lett. 2010, 43, 1301-1309. DOI:10.1080/00032710903518716

109. A. Parra, E. Casero, L. V'azquez, F. Pariente, E. Lorenzo, Anal. Chim. Acta 2006, 555, 308-315.

DOI:10.1016/j.aca.2005.09.025

110. K. Wang, J. Xu, H. Chen, Sens. Actuat. B Chem. 2006, 114, 1052-1058. DOI:10.1016/j.snb.2005.07.066

111. I. Bravo, M. Revenga-Parra, F. Pariente, E. Lorenzo, Sensors 2017, 17, 144-155. DOI:10.3390/s17010144

112. S. Kamanin, V. Arlyapov, V. Alferov, A. Reshetilov, Ferment. Technol. 2016, 5, 1. DOI:10.4172/2167-7972.1000128

113. B. Batra, V. Narwal, C. Pundir, Eng. Life Sci. 2016, 16, 786794. DOI:10.1002/elsc.201600082
114. M. Briones, E. Casero, L. Vazquez, F. Pariente, E. Lorenzo, M.D. Petit-Dominguez, Anal. Chim. Acta 2016, 908, 141149. DOI:10.1016/j.aca.2015.12.029

115. S. Yazid, I. Isa, S. Bakar, N. Hashim, S. Ghani, Anal. Lett., 2014, 47, 1821-1834. DOI:10.1080/00032719.2014.888731

116. R. Batool, A. Rhouati, M. Nawaz, A. Hayat, J. Marty, Biosensors, 2019, 9, 46 (19 pages).

DOI:10.3390/bios9010046

117. L. Rassaei, W. Olthuis, S. Tsujimura, E. Sudholter, A. Van der Berg, Anal. Bioanal. Chem. 2014, 406, 123-137. DOI:10.1007/s00216-013-7307-1

118. K. Rathee, V. Dhull, R. Dhull, S. Singh, Biochem. Biophys. Rep. 2016, 5, 35-54. DOI:10.1016/j.bbrep.2015.11.010

119. A. Uzunoglu, J. Electrochem. Soc. 2018, 165, B436-B441. DOI:10.1149/2.0601810jes

120. D. Hickey, R. Reid, R. Milton, S. Minteer, Biosens. Bioelectron. 2016, 77, 26-31. DOI:10.1016/j.bios.2015.09.013

121. A. M. Parra-Alfambra, E. Casero, L. Vázquez, C. Quintana, M. del Pozo, M. D. Petit-Domínguez, Sens. Actuat. B: Chemical 2018, 274, 310-317. DOI:10.1016/j.snb.2018.07.124

122. M. Briones, E. Casero, M.D. Petit-Dominguez, M.A. Ruiz, A.M. Parra-Alfambra, F. Pariente, E. Lorenzo, L. Vazquez, Biosens. Bioelectron. 2015, 68, 521-528. DOI:10.1016/j.bios.2015.01.044

123. D. Tu, Y. He, Y. Rong, Y. Wang, G. Li, Meas. Sci. Technol. 2016, 27, 045108 (7pp). DOI:10.1088/0957-0233/27/4/045108

124. C. Yang, S. Yu, Q. Yang, Q.Wang, S. Xie, H. Yang, J. Electrochem. Soc. 2018, 165, B665-B668. DOI:10.1149/2.0341814jes

125. X. Luo, W. Shi, H. Yu, Z. Xie, K. Li, Y. Cui, Sensors 2018, 18, 3398-3415. DOI:10.3390/s18103398

126. J. Pilas, Y. Yazici, T. Selmer, M. Keusgen, M. Schöning, Electrochim. Acta 2017, 251, 256-262. DOI:10.1016/j.electacta.2017.07.119

127. J. Pilas, Y. Yazici, T. Selmer, M.Keusgen, M. Schöning, Sensors 2018, 18, 1470-1482. DOI:10.3390/s18051470

\section{Povzetek}

V preteklih dveh desetletjih so elektrokemijski biosenzorji vzbudili veliko zanimanja na področju analize živil, predvsem zaradi svojih privlačnih delovnih karakteristik. V prehrambeni industriji kontrola kvalitete med proizvodnjo ter končnih izdelkov zahteva hitre in zanesljive analizne metode. Obetavna alternativa tradicionalnim analiznim metodam so elektrokemijski encimatski biosenzorji - naprave, ki kombinirajo robustnost elektrokemijskih tehnik s specifičnostjo biološke prepoznave ter ponujajo veliko prednosti zaradi svoje velikosti, cene, občutliivosti, selektivnosti in hitrega odziva. Pričujoči kratki pregled literature poskuša povzeti objave v zadnjem obdobju na temo napredka v razvoju encimskih biosenzorjev z amperometrijsko detekcijo za kvantitativno analizo glukoze in laktata v različnih živilskih vzorcih. Pregled se zaključi $z$ napovedjo bodočih izzivov in perspektiv na tem področju.

Except when otherwise noted, articles in this journal are published under the terms and conditions of the Creative Commons Attribution 4.0 International License 